\title{
Patterns and predictors of gestational weight gain in Addis Ababa, Central Ethiopia: a prospective cohort study
}

Fekede Asefa ${ }^{1,2,3^{*}} \mathbb{D}$, Allison Cummins ${ }^{2}$, Yadeta Dessie ${ }^{1}$, Maralyn Foureur ${ }^{2,4}$ and Andrew Hayen ${ }^{3}$

\begin{abstract}
Introduction: Gaining excessive or inadequate gestational weight is associated with many adverse maternal and fetal outcomes. Inadequate gestational weight gain (GWG) increases the risk of fetal growth restriction, pre-term birth, and low birth weight. It is a public health concern in sub-Saharan Africa. The aim of this study was to assess the patterns and predictors of GWG in Addis Ababa, Ethiopia.

Methods: We conducted a prospective cohort study among pregnant women who attended antenatal care in health centres in Addis Ababa, from January to September 2019. Data were collected by a structured questionnaire and checklists and analysed using Stata version-14. Weight at or before 16 weeks gestation was used as a proxy for pre-pregnancy weight. Women's height and baseline weight were measured by data collectors, and we obtained weight at the end of the 24th and 36th weeks of gestation from women's medical records. GWG was categorized as inadequate, adequate and excessive based on the United States Institute of Medicine criteria. Predictors of GWG were identified using multinomial logistic regression.
\end{abstract}

Results: A total of 395 pregnant women were enrolled in the study. GWG was assessed for 369 (93\%) women. The median GWG was $8.7 \mathrm{~kg}$ with inter quartile ranges (25th, 75th percentiles) of $7.0 \mathrm{~kg}$ and $11.6 \mathrm{~kg}$. More than two-third of the participants, 248 (67.2\% [95\% Cl: 62.2, 72.0\%]), gained inadequate weight; 103 (27.9\% [95\% Cl: 23.4, 32.8\%]) gained adequate weight; and 18 (4.9\% [95\% Cl: 2.9\%, 7.6\%]) gained excessive weight. Three quarters (75\%) of underweight women gained inadequate gestational weight, whereas $43 \%$ of overweight or obese women gained inadequate gestational weight. Being underweight ( $\mathrm{AOR}=3.30[95 \% \mathrm{Cl}: 1.32,8.24]$ ) or normal weight (AOR $=2.68$ [95\% Cl: $1.37,5.24]$ ) before pregnancy increased the odds of gaining inadequate gestational weight compared to overweight or obese women. Not having paid employment was associated with higher odds of gaining inadequate gestational weight compared to women employed outside the home (AOR=2.17 [95\% Cl: 1.16, 4.07]).

Conclusions: Most pregnant women in Addis Ababa gain inadequate gestational weight. In particular, three quarters of underweight women gained inadequate gestational weight. Being underweight, normal weight or having no paid employment were associated with higher odds of inadequate GWG. Promoting adequate GWG in Addis Ababa among underweight and normal weight women may be an important public health initiative.

*Correspondence: sinboona@gmail.com

${ }^{1}$ School of Public Health, College of Health and Medical Sciences, Haramaya University, Harar, Ethiopia

Full list of author information is available at the end of the article permits use, sharing, adaptation, distribution and reproduction in any medium or format, as long as you give appropriate credit to the original author(s) and the source, provide a link to the Creative Commons licence, and indicate if changes were made. The images or other third party material in this article are included in the article's Creative Commons licence, unless indicated otherwise in a credit line to the material. If material is not included in the article's Creative Commons licence and your intended use is not permitted by statutory regulation or exceeds the permitted use, you will need to obtain permission directly from the copyright holder. To view a copy of this licence, visit http://creativecommons.org/licenses/by/4.0/. The Creative Commons Public Domain Dedication waiver (http://creativeco mmons.org/publicdomain/zero/1.0/) applies to the data made available in this article, unless otherwise stated in a credit line to the data. 


\begin{abstract}
Plain language summary
Pregnant women are expected to gain weight due to various biological changes. Gaining inadequate or excessive weight during pregnancy poses a health risk to the mother and baby. Inadequate weight gain is a public health concern in low-income countries, including Ethiopia. This study assessed patterns and predictors of weight gain during pregnancy in Addis Ababa, Central Ethiopia. The study was conducted from January to September 2019. Women attending public health facilities were followed from before or at 16 weeks of gestation until 36 weeks of pregnancy. A total of 395 pregnant women enrolled in the study. Weight gain was assessed for 369 (93\%) women. More than twothird of the participants (67.2\%) gained inadequate weight during pregnancy. Three quarters (75\%) of underweight women gained inadequate weight, whereas $43 \%$ of overweight or obese women gained inadequate weight during pregnancy. Promoting adequate weight gain during pregnancy for underweight and normal weight women in Addis Ababa is an important public health initiative.
\end{abstract}

Keywords: Gestational weight gain, Predictors, Body mass index, Ethiopia

\section{Introduction}

Gestational weight gain (GWG) is defined as the amount of weight gain from conception until the birth of the baby. The recommended amount of GWG varies based on pre-pregnancy body mass index (BMI) of the women. According to the 2009 United State Institute of Medicine (IOM) recommendations women with $\mathrm{BMI} \leq 18.5 \mathrm{~kg} / \mathrm{m}^{2}$ are recommended to gain $12.5-18 \mathrm{~kg}$; women with BMI $18.6-24.9 \mathrm{~kg} / \mathrm{m}^{2}$ are recommended to gain $11.5-16 \mathrm{~kg}$; women with BMI 25.0 to $29.9 \mathrm{~kg} / \mathrm{m}^{2}$ are recommended to gain $7-11.5 \mathrm{~kg}$; and women with $\mathrm{BMI} \geq 30.0 \mathrm{~kg} / \mathrm{m}^{2}$ are recommended to gain $5-9 \mathrm{~kg}$ [1].

Most studies have reported that fewer than a third of pregnant women gain adequate gestational weight [211]. The majority of women in high income countries such as the United States (73\%) [2] and Canada (71\%) [6] gain an excessive amount of gestational weight. In contrast, inadequate GWG is a major public health concern in low-income Sub-Saharan African countries [12, 13] where studies showed that $69 \%$ of pregnant women from eastern Ethiopia, Harar [5], and $62.7 \%$ of pregnant women from low income settings such as urban Uganda, Kampala [14] gained inadequate gestational weight. Pregnant women who gain inadequate weight are at a higher risk of bearing a baby with low birth weight (LBW) and pre-term birth [3, 15-17]. In Ethiopia, the prevalence of LBW (17\%) [18] and preterm birth (26\%) [19] are among the highest worldwide. On the other hand, women who gained excessive gestational weight are at a higher risk of developing gestational hypertension [2, 3], gestational diabetes [2], caesarean birth [20], high postpartum weight retention [4], and long term obesity [21].

The amount of GWG is associated with numerous factors. These include health system related factors (antenatal care including advice and follow-up from health care providers) [22-24], and women's own related factors (physiological factors, psychological, and behavioural factors) [1, 25-27]. Women's age [5], pre-pregnancy maternal weight $[5,28,29]$, multi-parity $[6,7]$, women's awareness of healthy eating and dietary diversity [30], attending antenatal care [5], and engaging in physical activity $[5,31]$ are all related to the amount of GWG.

Studies from high-income countries report that household food insecurity is associated with excessive GWG $[32,33]$. However, this needs further investigation in low-income countries where women suffer from nutritional deficiencies in households with food insecurity [34, 35]. Furthermore, household food insecurity is strongly associated with low nutritional status such as being underweight [36, 37], decreased mid-upper arm circumference (MUAC) [34, 37], and anaemia [38]. Though some authors [32, 33] have argued that food insecurity causes excessive GWG leading to maternal depression, it is unclear whether food insecurity causes maternal depression or maternal depression causes food insecurity [39].

Having a history of intimate partner violence during pregnancy is associated with gaining less weight during pregnancy $[40,41]$. Despite the high levels of intimate partner violence in Ethiopia (emotional violence 24.0\%, physical violence $24.9 \%$ and sexual violence $11.1 \%$ ) [42], its effect on GWG is not well studied.

Few studies have been conducted in Ethiopia focusing on GWG [5, 43, 44]. Published studies have retrospectively assessed GWG and prospective studies are recommended [13]. Retrospective studies have not addressed some important predictor variables such as physical activity, food insecurity, perinatal depression, and intimate partner violence during pregnancy. The aim of the current study was to assess the patterns and predictors of GWG in Addis Ababa, central Ethiopia.

\section{Methods \\ Study setting}

This study was conducted in Addis Ababa, which is the capital and largest city in Ethiopia. In the city, there are 
42 hospitals (11 government, 6 non-government organisations, and 25 private), 97 Health Centres, and 361 clinics that provide medical care including maternal health care $[45,46]$. Around $97 \%$ of pregnant women in Addis Ababa receive antenatal care (ANC) from skilled care providers such as doctors, nurses or midwives, at least once [42], of which 90\% receive at least four ANC contacts [47].

\section{Study design}

A prospective cohort study design was employed from January 2019 to September 2019.

\section{Sample size determination}

We calculated the sample size using Open Epi Version 2.3 considering both the single proportion formula (to assess the proportion of GWG) and the double proportion formula (to assess predictors of GWG). The larger sample size was achieved by using the single proportion formula considering the proportion of women with inadequate gestational weight from a study conducted in Harar, Ethiopia $(p=0.69)$ [5], a half-width of confidence 5\%, an alpha value of 0.05 , and $20 \%$ loss to follow-up. The final sample size was 395 .

\section{Participants and sampling procedure}

The women were selected from nine health centres. The health centres were selected based on the number of ANC visits and geographic location in the city. Women who met the inclusion criteria were consecutively selected from each health facility until the required sample size was met.

We invited all pregnant women in their first trimester (before 16 weeks gestation) who came to the selected health centres for antenatal care (Additional file 1: Table S1). Antenatal clinic staff who provided the antenatal care facilitated the participant selection process. They also assisted in setting appointment dates for the followup data collection (at the end of the 24th and 36th weeks of gestation). Women with a twin-pregnancy or with co-morbidities such as diabetes and hypertension were excluded from the study.

\section{Measurements}

We collected data through face-to-face interviews and review of health records. We used a range of tools to collect data on socio-demographic characteristics, dietary diversity and food security, intimate partner violence, physical activity and depression related symptoms. Variables such as gestational age (ultrasound result), blood pressure, random blood sugar, anaemia status, and HIV status were obtained from medical records of the women. Principal component analysis was employed to compute a wealth index [48] from a set of household assets questions such as electricity, refrigerator, table, chair, watch, phone, bed with mattress, electric mitad (an Ethiopian oven made up of clay and metal), car, house, improved water, and improved toilet, which were adapted from the Ethiopian demographic and health survey [42].

Gestational age was estimated by the last menstrual period and verified by ultrasound which was a routine practice of the health facilities. The gestational age of our study participants ranged from four to 16 weeks (8.9\% were between four and seven weeks of gestation; $41.1 \%$ were between eight and 12 weeks of gestation; and $50 \%$ were between 13 and 16 weeks of gestation). The height of the women was measured when barefoot using a height measuring board in a standing position and recorded to the nearest $0.1 \mathrm{~cm}$. The maternal weight was measured by a digital weight scale with minimum clothing and the reading was recorded to the nearest $100 \mathrm{~g}$. We asked women if they knew their pre-pregnancy weight, however only 172 (43.5\%) of the participants were aware of their pre-pregnancy weight. Therefore, we used weight at or before 16 weeks as a proxy for pre-pregnancy weight in all women. Women's height and baseline weight were measured by data collectors, while weight at the end of 24th and 36th weeks of gestation was collected from women's medical records. Body Mass Index (BMI) was calculated by dividing weight by height, squared. The women's BMI at or before 16 weeks of gestation (for those whose ages were $\geq 20$ years old) was categorized into four categories based on the World Health Organization BMI cut-off points as underweight $\left(\mathrm{BMI} \leq 18.5 \mathrm{~kg} / \mathrm{m}^{2}\right)$; normal weight (18.6 to $24.9 \mathrm{~kg} / \mathrm{m}^{2}$; overweight (25.0 to $\left.29.9 \mathrm{~kg} / \mathrm{m}^{2}\right)$; and obese $(\geq 30.0 \mathrm{~kg} /$ $\mathrm{m}^{2}$ ). BMI-for-age (at or before 16 weeks of gestation) was calculated for adolescent women (women aged 18 and 19 years old); and BMI was categorized using WHO reference cut-off points as thin (Z-score $<-2$ standard deviation (SD)), normal ( $-2 \mathrm{SD} \leq \mathrm{Z}$-score $\leq+1 \mathrm{SD})$, overweight $(+1 \mathrm{SD}<\mathrm{Z}$-score $\leq+2 \mathrm{SD})$ and obese (Z-score $>+2 \mathrm{SD})$. Total weight gain was calculated by subtracting the prepregnancy weight from their weight at the 4th antenatal care visit (at the end of 36 weeks of gestation). It was categorized as inadequate, adequate and excessive according to the IOM classification. Mid upper arm circumference (MUAC) was measured using an adult MUAC nonstretchable measuring tape and the reading was taken to the nearest $0.1 \mathrm{~cm}$. A MUAC measurement below $23 \mathrm{~cm}$ was categorised as low (or wasting) and above $23 \mathrm{~cm}$ was categorized as normal.

Dietary diversity of the women was assessed using a minimum dietary diversity-women (MDD-W) set from the Food and Agricultural Organisation (FAO) and USAID's Food and Nutrition Technical Assistance 
III Project (FANTA) [49]. The food groups assessed in MDD-W include: grains, white roots, tubers and plantains; pulses; nuts and seeds; dairy; meat, poultry and fish; eggs; vegetables; other vitamin A-rich fruits and vegetables; other vegetables; and other fruits. The MDD-W is a dichotomous indicator of whether or not women have consumed at least five out of ten defined food groups the previous day or night. The proportion of women who reach this minimum can be used as a proxy indicator for higher micronutrient adequacy.

Household food insecurity was assessed using the Household Food Insecurity Access Scale (HFIAS). In each domain of the HFIAS questions ask about anxiety and uncertainty; insufficient quality; and insufficient food intake and any physical consequences, with a recall period of four weeks (30 days)[50].

Women's physical activity level was measured using the International Physical Activity Questionnaire (IPAQ-long form). The IPAQ assesses physical activity across a range of different domains including recreation-time, housework, being employed and transportation related physical activities. Each domain assesses walking, moderate and vigorous physical activities over a seven day period. Women were asked if they had completed these activities continuously for at least $10 \mathrm{~min}$. Responses to IPAQ questions on the frequency and duration of physical activity were converted to the metabolic equivalent task per minute (MET-minutes) [51]. A MET is the ratio of specific physical activity metabolic rates to the resting metabolic rate, with one MET defined as the energy needed by an individual while at complete rest, which is equivalent to 1 kilocalorie per kilogram per hour [52].

The level of physical activity for each woman was categorized as;

- High-the woman accumulated at least 1500 METminutes per week from vigorous-intensity activity on at least 3 days; or accumulated at least 3000 METminutes per week on seven or more days of any combination of walking, moderate- or vigorous-intensity activities;

- Moderate-the woman engaged in three or more days of vigorous-intensity activity of at least $20 \mathrm{~min}$ per day; five or more days of moderate-intensity activity and/or walking of at least $30 \mathrm{~min}$ per day; or five or more days of any combination of walking, moderate-intensity or vigorous intensity activities achieving a minimum of at least 600 MET-minute per week,

- Low-the woman reported no activity or some, but not enough to meet the high and moderate categories [51].
Perinatal depression symptoms were measured using the Edinburgh postnatal depression scale (EPDS) [53], which is a ten-item questionnaire. It has been validated and used by many studies for detecting perinatal depression in Ethiopia [54-57].

Intimate partner violence was measured with a questionnaire used by the WHO multi-country study on women's health and domestic violence [58]. It includes physical violence, sexual violence and emotional abuse by intimate partners. This questionnaire has also been used in the Ethiopian Demographic and Health Survey (EDHS) 2016 [42], making the survey suitable to use in the current study setting.

\section{Statistical analysis}

Data were entered into CSPro version 7.1, and exported to STATA (V.14, Stata Corp, 2015) for analysis. Frequencies and proportions were estimated to describe the variables. BMI-for-age was calculated for adolescent pregnant women using WHO AnthroPlus software. We conducted bivariable and multivariable analyses using a multinomial logistic regression model, because the outcome variable (i.e., GWG) consisted of three categories (inadequate, adequate and excessive GWG). Pregnant women with inadequate or excessive GWG were compared to women with adequate GWG (reference category). Variables with $P$-value $<0.25$ in the bivariate analysis were included in the multivariable analyses. The variables in the multivariable analyses included educational status, wealth index, occupational status, BMI, MUAC, perinatal depression and asking permission from partners for health care seeking. Crude odds ratios (COR) and adjusted odds ratios (AOR) were calculated to determine the association between the explanatory variables and GWG.

\section{Results}

We enrolled 395 women into the study. Of these women, we recorded GWG for 369 women with a follow-up rate of $93.4 \%$ (Fig. 1).

\section{Socio-demographic characteristics}

The mean age of the women was 25.3 (standard deviation $=3.9$ ) years, and $80.5 \%$ were between 20 and 29 years of age. Most of the respondents (96.5\%) were married; 9.7\% never attended formal education; and $50.6 \%$ were not employed outside of the home. All were urban residents. Seventy two (72\%) percent of the respondents had an estimated income of $<200$ USD per month. Ninety percent $(90 \%)$ of the pregnancies were intended; almost half $(49.6 \%)$ of the women were primigravida (Table 1 ). 


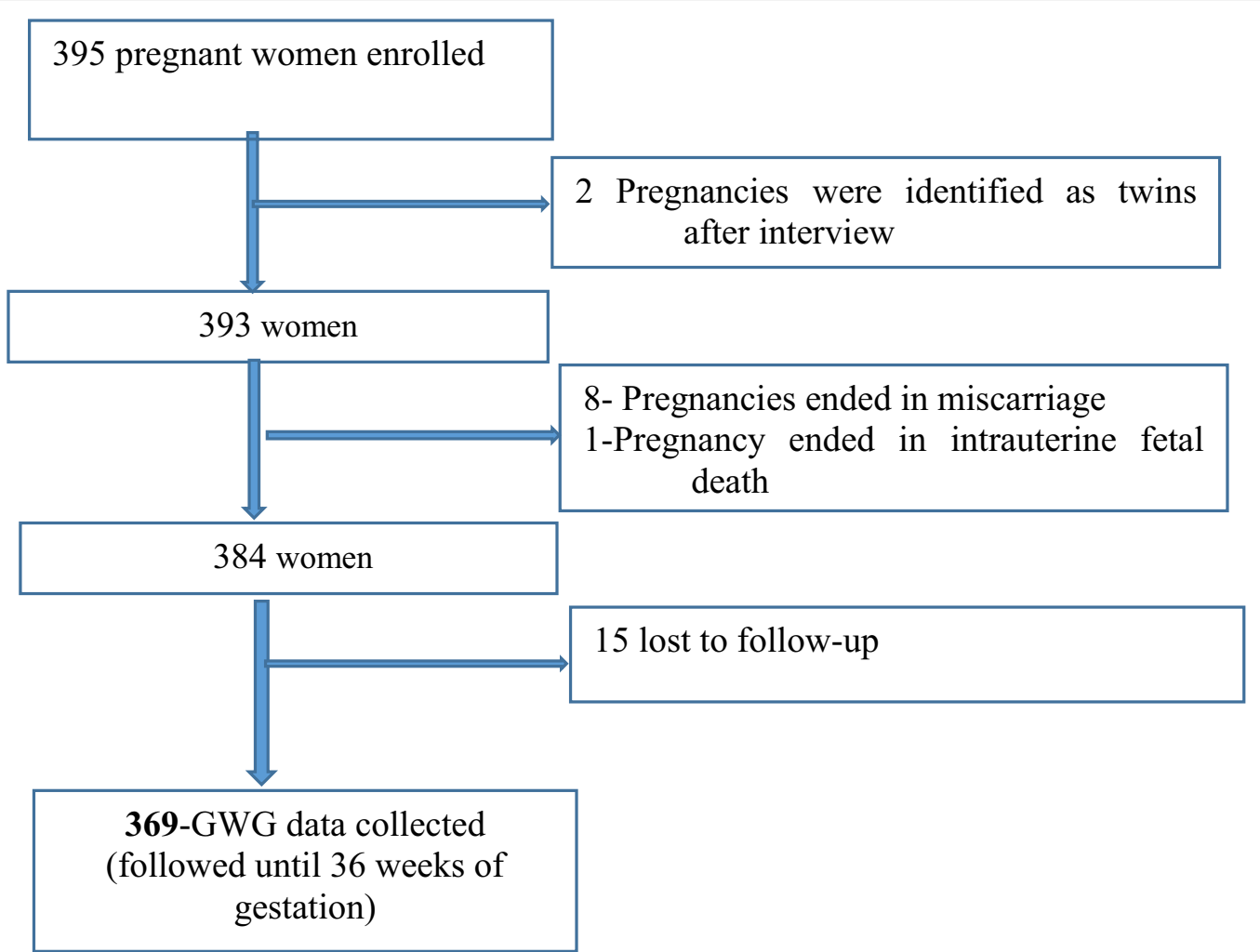

Fig. 1 Flow chart of study participants' follow-up in Addis Ababa, Ethiopia, 2019

\section{BMI and GWG of the study participants}

The mean BMI of the respondents (with age $\geq 20$ years old) at or before 16 weeks of gestation (which was a proxy for pre-pregnancy weight) was 21.83 $(\mathrm{SD}=3.28 \mathrm{~kg} / \mathrm{m} 2) ; 18.1 \%$ had a BMI of $\leq 18.5 \mathrm{~kg} / \mathrm{m}^{2}$; $63.7 \%$ had a BMI between 18.5 and $24.9 \mathrm{~kg} / \mathrm{m}^{2} ; 17.3 \%$ had a BMI between 25 and $29.9 \mathrm{~kg} / \mathrm{m}^{2}$; and $0.9 \%$ had a $\mathrm{BMI} \geq 30 \mathrm{~kg} / \mathrm{m}^{2}$. According to the BMI-for-age of adolescent pregnant women (aged 18 and 19 years old): $5.0 \%$ were thin; $80.0 \%$ were normal weight; $10.0 \%$ were overweight; and $5.0 \%$ were obese. Women were asked if they knew their pre-pregnancy weight, however only $172(43.5 \%)$ of the participants were aware of their prepregnancy weight. The median GWG was $8.7 \mathrm{~kg}$ with inter quartile ranges (IQR) (25th, 75th percentiles) of $7 \mathrm{~kg}$ and $11.6 \mathrm{~kg}$; underweight women gained a median weight of $10.0 \mathrm{~kg}$ with IQR of $7.6 \mathrm{~kg}$ and $12.5 \mathrm{~kg}$ while overweight or obese women gained a median weight of $7.0 \mathrm{~kg}$ with IQR of $5.0 \mathrm{~kg}$ and $8.2 \mathrm{~kg}$ (Table 2). Of 369 women for whom GWG was assessed, $67.2 \%$ (95\% CI: $62.2,72.0 \%$ ) gained inadequate gestational weight; $27.9 \%$ (95\% CI: $23.4,32.8 \%$ ) gained adequate gestational weight; and 4.9\% (95\% CI: 2.9, 7.6\%) gained excessive gestational weight. Three quarters (75\%) of underweight women gained inadequate gestational weight whereas $43 \%$ of overweight or obese women gained inadequate gestational weight.

\section{Dietary diversity, food security, and anaemia status}

Within the previous 24 hours before the interview, 95.6\% of the participants consumed foods prepared from grains; $28.4 \%$ consumed meat and meat product; and $6.4 \%$ consumed fish and fish products. Women's dietary diversity score varied from 1 to 10 , with $17.2 \%$ having a low dietary diversity score. Thirteen percent of the study participants were living in food-insecure households; $3 \%$ had anaemia (2.4\% had mild anaemia; $0.3 \%$ each had moderate and severe anaemia); and $18 \%$ had low MUAC value $(<23 \mathrm{~cm})$ (Table 3).

\section{Respondents' physical activity status}

Of the total study participants, $5.3 \%$ reported doing vigorous-intensity physical activity that lasted for at least 10-minutes continuously while at work. Whereas $14 \%$ reported doing moderate-intensity physical activity for at least 10-minutes continuously while at work. Moderate-intensity inside chores and activities were the most commonly practiced physical activities (98.2\%) among women. Vigorous- and moderate-intensity leisure-time 
Table 1 Baseline demographic characteristics of the study participants in Addis Ababa, Ethiopia, 2019 ( $n=395$ )

\begin{tabular}{|c|c|c|}
\hline Variable & Frequency & Percentage \\
\hline \multicolumn{3}{|l|}{ Age } \\
\hline Less than 20 years & 20 & 5.0 \\
\hline 20-29 years & 318 & 80.5 \\
\hline 30-39 years & 56 & 14.3 \\
\hline Greater than 40 years & 1 & 0.2 \\
\hline \multicolumn{3}{|l|}{ Marital status (395) } \\
\hline Never married & 14 & 3.5 \\
\hline Married & 381 & 96.5 \\
\hline \multicolumn{3}{|l|}{ Educational status (394) } \\
\hline No formal education & 38 & 9.7 \\
\hline Primary education (1-8) & 162 & 41.1 \\
\hline Secondary education (9-12) & 112 & 28.4 \\
\hline Tertiary education & 82 & 20.8 \\
\hline \multicolumn{3}{|l|}{ Partners' educational status (395) } \\
\hline No formal education & 32 & 8.1 \\
\hline Primary education (1-8) & 99 & 25.1 \\
\hline Secondary education (9-12) & 147 & 37.2 \\
\hline Tertiary education & 117 & 26.6 \\
\hline \multicolumn{3}{|l|}{ Occupational status } \\
\hline No paid employment (home duties) & 200 & 50.6 \\
\hline Government/private employee & 126 & 31.9 \\
\hline Merchant & 39 & 9.9 \\
\hline Student & 8 & 2.0 \\
\hline Daily labourer & 12 & 3.0 \\
\hline Other* & 10 & 2.6 \\
\hline \multicolumn{3}{|l|}{ Estimated average monthly income (364) } \\
\hline$\leq \$ 200$ USD & 263 & 72.3 \\
\hline$>\$ 200$ USD & 101 & 27.7 \\
\hline \multicolumn{3}{|l|}{ Type of pregnancy (388) } \\
\hline Intended & 351 & 90.5 \\
\hline Unintended & 37 & 9.5 \\
\hline \multicolumn{3}{|l|}{ Gravidity (395) } \\
\hline Primigravida & 196 & 49.6 \\
\hline Multigravida & 199 & 50.4 \\
\hline
\end{tabular}

*farmer, waitress, selling coffee and tea on the street, freelance researcher activities were the least commonly practiced among women (Fig. 2).

The MET minutes per week (median (interquartile range)) of the women were $742(330,2145)$ for job related physical activities; $360(180,630)$ for domestic and garden work; 231 (132, 346) for recreation and leisure related physical activities; and $231(132,396)$ for transportation related physical activities. The proportion of women who engaged in a high, moderate and low level of physical activity was $10.9 \% ; 42.0 \%$ and $47.1 \%$, respectively.

\section{Intimate partner violence and perinatal depression}

Of the total respondents, $18.2 \%$ experienced intimate partner violence (any physical, sexual or emotional violence) during their current pregnancy; $6.6 \%$ experienced physical violence; $7.3 \%$ sexual violence; and $8.1 \%$ emotional violence. Forty one percent $(41 \%)$ asked permission from their partners to seek health care. Ten percent (10\%) of the respondents had symptoms related to perinatal depression.

\section{Predictors of gestational weight gain}

Seventy seven percent (77\%) of women who did not attend formal education gained inadequate gestational weight, while $56 \%$ of women who attended tertiary education gained inadequate gestational weight. Seventy six percent (76\%) of women with no paid employment outside of home (home duties) gained inadequate gestational weight, however $55 \%$ of women who were employed by a government or private institution gained inadequate weight. Fourteen percent (14\%) of women with perinatal depression gained excessive gestational weight compared to women with no perinatal depression (4\%).

A multivariable regression model included: women's educational status, occupation, wealth index, pre-pregnancy BMI, maternal mid-upper arm circumference, perinatal depression and whether the women had asked permission from their partners to seek health care. Compared to overweight or obese women, being underweight $(\mathrm{AOR}=3.30$ [95\% CI: 1.32, 8.24] $)$ and normal weight $(\mathrm{AOR}=2.68$ [95\% CI: 1.37, 5.24] $)$ increased the odds of gaining inadequate gestational weight. Similarly, Not

Table 2 Patterns of gestational weight gain by specific body mass index at specific trimester in Addis Ababa, Ethiopia, 2019

\begin{tabular}{lccc}
\hline Weight status & $\begin{array}{l}\text { Second trimester GWG (Median and } \\
\text { IQR (25th, 75th percentiles) }(\mathbf{n}=\mathbf{3 2 8})\end{array}$ & $\begin{array}{l}\text { Third trimester GWG (Median and } \\
\text { IQR (25th, 75th percentiles) } \mathbf{( n = 3 2 4 )}\end{array}$ & $\begin{array}{l}\text { Total GWG (Median and } \\
\text { IQR (25th,75th percentiles) } \\
\text { ( } \mathbf{n}=\mathbf{3 6 9 )}\end{array}$ \\
\hline Underweight women & $5 \mathrm{~kg}(3.5,6.0)$ & $4.5 \mathrm{~kg}(3.0,6.6)$ & $10(7.6,12.5)$ \\
Normal weight women & $4 \mathrm{~kg}(3.0,5.7)$ & $5 \mathrm{~kg}(3.0,6.1)$ & $9 \mathrm{~kg}(7.0,12.0)$ \\
Overweight or obese women & $3.9 \mathrm{~kg}(1.0,5.7)$ & $4 \mathrm{~kg}(2.0,5.0)$ & $7 \mathrm{~kg}(5.0,8.2)$ \\
Total & $4 \mathrm{~kg}(2.9,6.0)$ & $4.5 \mathrm{~kg}(3.0,6.0)$ & $8.7 \mathrm{~kg}(7.0,11.6)$ \\
\hline
\end{tabular}


Table 3 Dietary diversity, food security, anaemia status of the study participants in Addis Ababa, Ethiopia, 2019 ( $n=395)$

\begin{tabular}{lcc}
\hline Variable & Frequency & Percentage \\
\hline Food group consumed in the last 24 $\mathrm{h}$ & & \\
Foods from grains & 377 & 95.7 \\
White roots, tubers and plantains & 273 & 69.3 \\
Pulses (bean, peas and lentils) & 264 & 67.0 \\
Milk and milk products & 138 & 35.0 \\
Meat and meat product & 112 & 28.4 \\
Any fresh or dried or shellfish & 25 & 6.4 \\
Eggs & 89 & 22.6 \\
Vegetable & 229 & 58.1 \\
Fruits & 229 & 58.1 \\
Any foods made with oil or fat & 341 & 86.6 \\
Minimum dietary diversity & & \\
Low dietary diversity & 68 & 17.2 \\
High dietary diversity & 327 & 82.8 \\
Food Security (391) & & \\
Food secure & 340 & 87.0 \\
Mildly food insecure & 19 & 4.9 \\
Moderately food insecure & 26 & 6.6 \\
Severely food insecure & 6 & 1.5 \\
MUAC (387) & & \\
Low MUAC (<23 cm) & 77.0 & 18.1 \\
High MUAC ( $\geq 23$ cm) & 317 & \\
Had anaemia (385) & & \\
Yes & & \\
No & & \\
\hline
\end{tabular}

having paid employment, $(\mathrm{AOR}=2.17$ [95\% CI: 1.16 , $4.07]$ ), was associated with higher odds of gaining inadequate gestational weight compared to women employed by the government or private institutions. The odds of inadequate GWG in the second lowest wealth quartile was $61 \%$ less than in lowest wealth quartile women (Table 4).

\section{Discussion}

We found that more than two thirds of women (67.2\%) gained inadequate gestational weight. In contrast, fewer than $5 \%$ of women gained excess gestational weight. Being underweight or normal weight before pregnancy increased the odds of gaining inadequate gestational weight. Similarly, not having paid employment (home duties) was associated with higher odds of gaining inadequate gestational weight compared to women employed by government or private institutions. The odds of inadequate GWG for women in the second lowest wealth quartile was $61 \%$ less than women in lowest wealth quartile.
Inadequate gestational weight gain was high in our study, with more than two-thirds of women gaining inadequate gestational weight. This may be due to some women in Ethiopia decreasing food consumption during pregnancy fearing that overeating may enlarge the fetal head or make the baby overweight and that will lead to a caesarean birth $[59,60]$. Wang et al. recently used data from the demographic health survey program to estimate the average levels of GWG in all low and middle income countries (LMIC) and found that the average level of GWG is lower than the United State Institute of Medicine recommendations in most LMIC countries [13]. Our findings are consistent, however, with other studies in sub-Saharan Africa, including the proportions of women with inadequate gestational weight gain of $71.8 \%$ in Malawi [61], 63\% in Niger [62], and 62.7\% in Uganda [14]. A higher proportion of women with inadequate GWG in these low-income sub-Saharan Africa settings, including Ethiopia, could be as a result of a wide range of nutritional problems, economic instability, poverty, food insecurity, and frequent infections which are common in sub-Saharan Africa [63]. In addition, a significant proportion of women were underweight at the time of conception in sub-Saharan Africa [5, 12, 64]. Moreover, more than a half of pregnant women in sub-Saharan African settings lack awareness of the risks associated with inappropriate GWG [65]. Given the adverse maternal and child health outcomes associated with inadequate GWG [43, 66-68], our findings indicate that inadequate GWG is a public health concern in Addis Ababa, Ethiopia and highlights the need for effective maternal health interventions to influence weight gain during pregnancy.

Our findings contrast with high-income countries where a higher proportion of women with excessive GWG have been reported, where the majority of women experience excessive GWG [2, 6, 7]. Adequate gestational weight gain was found in fewer than one-third (27.9\%) of our study participants, which is similar to many other studies [2-11]. This would indicate that the practical applicability of the IOM guideline needs further investigation. The IOM guidelines are explicitly intended as recommendations for women in the United States which may be applicable for women in other high-income countries. The IOM guidelines were primarily intended to prevent excessive GWG. However, previous studies conducted in LMIC have used the IOM guidelines to facilitate comparisons across countries, as there are no specific guidelines for gestational weight gain for LMIC. This highlights the urgent need for GWG recommendations dedicated to LMIC or consideration of data from LMIC.

The prevalence of inadequate GWG was $75 \%$ among underweight women, compared with $43 \%$ among 


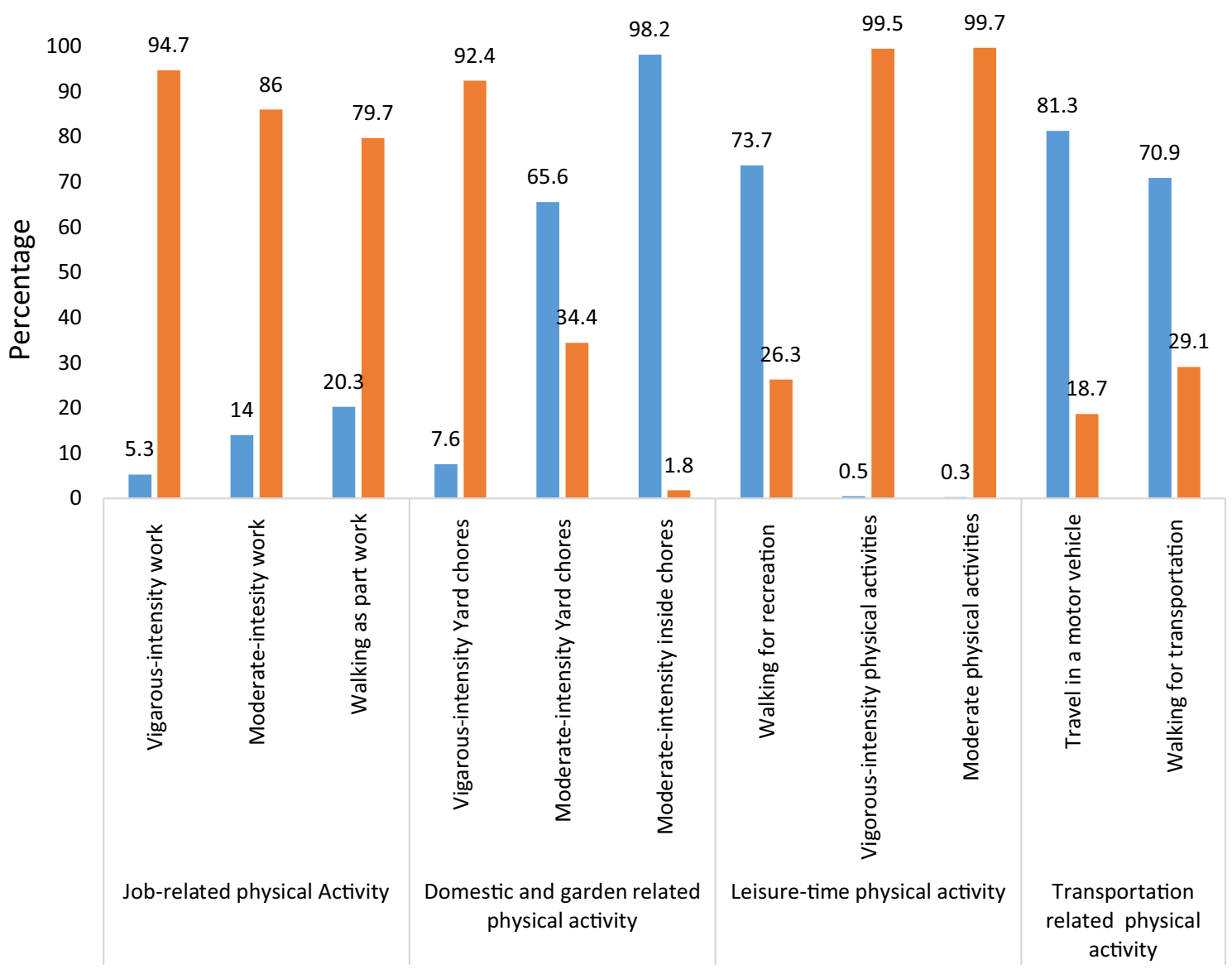

Type of physical activity

Fig. 2 Proportion of women who engage in physical activity by specific domains and intensity level in Addis Ababa, Ethiopia, 2019

overweight or obese women. Studies from sub-Saharan African countries have also reported that more than three-quarters of women who were underweight at the conception of the pregnancy gain gestational weight below the IOM recommendations [5, 64]. In our study, being underweight increased the odds of gaining inadequate gestational weight three-fold, while being normal weight increased the odds of gaining inadequate gestational weight two-fold, compared to overweight or obese women. This is due to the fact that pre-pregnancy $\mathrm{BMI}$ is closely linked to maternal nutrition, lifestyle and socio-cultural factors, which could have an impact on the amount of GWG [69]. Women who are underweight or normal weight before pregnancy are required to gain more weight than their overweight or obese counterparts to achieve a healthy GWG. Overweight and obese women, on the other hand, are required to gain comparatively little weight to achieve adequate GWG as they are able to use a portion of their stored energy to support the growth of the fetus. As such, adequate GWG may be attained easily for these women. This would potentially provide further evidence for strategies to support the promotion of adequate gestational weight gain in Ethiopian underweight and normal weight women.

We identified that not being in paid employment was associated with higher odds of inadequate GWG compared to women employed outside the home by government or private institutions. This could be due to half of 
Table 4 Predictors of gestational weight gain in Addis Ababa, Ethiopia, 2019

\begin{tabular}{|c|c|c|c|c|c|c|c|c|c|}
\hline \multirow[b]{2}{*}{ Variable } & \multicolumn{3}{|c|}{ Proportions of GWG } & \multicolumn{3}{|c|}{ Inadequate vs Adequate } & \multicolumn{3}{|c|}{ Excess vs Adequate } \\
\hline & $\begin{array}{l}\text { Inadequate } \\
\text { GWG n(\%) }\end{array}$ & $\begin{array}{l}\text { Adequate } \\
\text { GWG n(\%) }\end{array}$ & $\begin{array}{l}\text { Excess GWG } \\
n(\%)\end{array}$ & $\begin{array}{l}\text { Crude Odds } \\
\text { Ratio (COR) }\end{array}$ & $\begin{array}{l}\text { Adjusted } \\
\text { Odds Ratio } \\
\text { (AOR) }\end{array}$ & $\begin{array}{l}P \text {-value for } \\
\text { AOR }\end{array}$ & $\begin{array}{l}\text { Crude Odds } \\
\text { Ratio (COR) }\end{array}$ & $\begin{array}{l}\text { Adjusted } \\
\text { Odds Ratio } \\
\text { (AOR) }\end{array}$ & $\begin{array}{l}P \text {-value for } \\
\text { AOR }\end{array}$ \\
\hline $\begin{array}{l}\text { Educational } \\
\text { status }\end{array}$ & \multicolumn{9}{|c|}{$P$-value $=0.184$} \\
\hline $\begin{array}{l}\text { No formal } \\
\text { education }\end{array}$ & $27(77.1)$ & $7(20.0)$ & $1(2.9)$ & $\begin{array}{l}2.69 \\
{[1.04,6.98]}\end{array}$ & $\begin{array}{l}2.16 \\
{[0.70,6.66]}\end{array}$ & 0.178 & $\begin{array}{l}1.07 \\
{[0.10,11.13]}\end{array}$ & $\begin{array}{l}1.20 \\
{[0.09,16.86]}\end{array}$ & 0.894 \\
\hline $\begin{array}{l}\text { Primary } \\
\text { education } \\
(1-8)\end{array}$ & $100(65.8)$ & $44(28.9)$ & $8(5.3)$ & $\begin{array}{l}1.59 \\
{[0.88,2.85]}\end{array}$ & $\begin{array}{l}1.34 \\
{[0.63,2.84]}\end{array}$ & 0.442 & $\begin{array}{l}1.36 \\
{[0.38,4.94]}\end{array}$ & $\begin{array}{l}1.60 \\
{[0.32,7.83]}\end{array}$ & 0.569 \\
\hline $\begin{array}{l}\text { Secondary } \\
\text { education } \\
(9-12)\end{array}$ & $77(74.0)$ & $22(21.2)$ & $5(4.8)$ & $\begin{array}{l}2.44 \\
{[1.26,4.75]}\end{array}$ & $\begin{array}{l}1.63 \\
{[0.74,3.60]}\end{array}$ & 0.159 & $\begin{array}{l}1.70 \\
{[0.41,7.09]}\end{array}$ & $\begin{array}{l}1.66 \\
{[0.33,8.41]}\end{array}$ & 0.542 \\
\hline $\begin{array}{l}\text { Tertiary edu- } \\
\text { cation }\end{array}$ & $43(55.8)$ & $30(39.0)$ & $4(5.2)$ & Reference & Reference & & Reference & Reference & \\
\hline $\begin{array}{l}\text { Wealth } \\
\text { quartile }\end{array}$ & \multicolumn{9}{|c|}{$P$-value $=0.247$} \\
\hline Lowest & $53(74.7)$ & $15(21.1)$ & $3(4.2)$ & Reference & Reference & & Reference & Reference & \\
\hline Second & $45(59.2)$ & $30(39.5)$ & $1(1.3)$ & $\begin{array}{l}0.42 \\
{[0.20,0.89]}\end{array}$ & $\begin{array}{l}0.39 \\
{[0.17,0.86]}\end{array}$ & 0.021 & $\begin{array}{l}0.17 \\
{[0.02,1.74]}\end{array}$ & $\begin{array}{l}0.09 \\
{[0.01,1.10]}\end{array}$ & 0.060 \\
\hline Middle & $53(70.7)$ & $18(24.0)$ & $4(5.3)$ & $\begin{array}{l}0.83 \\
{[0.38,1.82]}\end{array}$ & $\begin{array}{l}0.91 \\
{[0.39,2.12]}\end{array}$ & 0.832 & $\begin{array}{l}1.11 \\
{[0.21,5.76]}\end{array}$ & $\begin{array}{l}1.32 \\
{[0.22,7.94]}\end{array}$ & 0.762 \\
\hline Fourth & $53(69.7)$ & $18(23.7)$ & $5(6.6)$ & $\begin{array}{l}0.83 \\
{[0.38,1.82]}\end{array}$ & $\begin{array}{l}1.12 \\
{[0.46,2.72]}\end{array}$ & 0.806 & $\begin{array}{l}1.39 \\
{[0.28,6.79]}\end{array}$ & $\begin{array}{l}1.95 \\
{[0.33,11.46]}\end{array}$ & 0.459 \\
\hline Highest & $44(62.0)$ & $22(31.0)$ & $5(7.0)$ & $\begin{array}{l}0.57 \\
{[0.26,1.22]}\end{array}$ & $\begin{array}{l}0.83 \\
{[0.34,2.01]}\end{array}$ & 0.679 & $\begin{array}{l}1.14 \\
{[0.24,5.49]}\end{array}$ & $\begin{array}{l}1.63 \\
{[0.27,9.93]}\end{array}$ & 0.598 \\
\hline $\begin{array}{l}\text { Occupational } \\
\text { status }\end{array}$ & \multicolumn{9}{|c|}{$P$-value $=0.015$} \\
\hline Employee & $66(55.5)$ & $46(38.7)$ & $7(5.9)$ & Reference & Reference & & Reference & Reference & \\
\hline $\begin{array}{l}\text { Do not } \\
\text { have paid } \\
\text { employ- } \\
\text { ment }\end{array}$ & $140(76.1)$ & $37(20.1)$ & $7(3.8)$ & $\begin{array}{l}2.64 \\
{[1.56,4.45]}\end{array}$ & $\begin{array}{l}2.17 \\
{[1.16,4.07]}\end{array}$ & 0.016 & $\begin{array}{l}1.24 \\
{[0.40,3.86]}\end{array}$ & $\begin{array}{l}1.00 \\
{[0.26,3.83]}\end{array}$ & 0.998 \\
\hline Merchant & $26(66.7)$ & $10(25.6)$ & $3(7.7)$ & $\begin{array}{l}1.81 \\
{[0.80,4.12]}\end{array}$ & $\begin{array}{l}2.14 \\
{[0.81,5.61]}\end{array}$ & 0.123 & $\begin{array}{l}1.97 \\
{[0.43,8.93]}\end{array}$ & $\begin{array}{l}1.58 \\
{[0.26,9.68]}\end{array}$ & 0.623 \\
\hline Other & $16(59.3)$ & $10(37.0)$ & $1(3.7)$ & $\begin{array}{l}1.12 \\
{[0.46,2.68]}\end{array}$ & $\begin{array}{l}0.76 \\
{[0.29,2.01]}\end{array}$ & 0.585 & $\begin{array}{l}0.66 \\
{[0.07,5.95]}\end{array}$ & $\begin{array}{l}0.65 \\
{[0.06,6.92]}\end{array}$ & 0.723 \\
\hline \multicolumn{10}{|l|}{ Weight status } \\
\hline $\begin{array}{l}\text { Under- } \\
\text { weight }\end{array}$ & $51(75.0)$ & 15 (22.1) & $2(2.9)$ & $\begin{array}{l}3.52 \\
{[1.62,7.65]}\end{array}$ & $\begin{array}{l}3.30 \\
{[1.32,8.24]}\end{array}$ & 0.011 & $\begin{array}{l}0.48 \\
{[0.09,2.57]}\end{array}$ & $\begin{array}{l}0.25 \\
{[0.03,1.97]}\end{array}$ & 0.188 \\
\hline $\begin{array}{l}\text { N ormal } \\
\text { weight }\end{array}$ & $169(71.6)$ & $59(25.0)$ & $8(3.4)$ & $\begin{array}{l}2.97 \\
{[1.63,5.39]}\end{array}$ & $\begin{array}{l}2.68 \\
{[1.37,5.24]}\end{array}$ & 0.004 & $\begin{array}{l}0.49 \\
{[0.17,1.44]}\end{array}$ & $\begin{array}{l}0.39 \\
{[0.11,1.37]}\end{array}$ & 0.141 \\
\hline $\begin{array}{l}\text { Overweight } \\
\text { or obese }\end{array}$ & $28(43.1)$ & $29(44.6)$ & $8(12.3)$ & Reference & Reference & & Reference & Reference & \\
\hline MUAC & \multicolumn{9}{|c|}{ P-value $=0.187$} \\
\hline $\begin{array}{l}\text { Low MUAC } \\
(<23 \mathrm{~cm})\end{array}$ & $49(75.4)$ & $12(18.5)$ & $4(6.1)$ & $\begin{array}{l}1.85 \\
{[0.94,3.63]}\end{array}$ & $\begin{array}{l}1.94 \\
{[0.87,4.32]}\end{array}$ & 0.103 & $\begin{array}{l}2.10 \\
{[0.59,7.42]}\end{array}$ & $\begin{array}{l}6.63 \\
{[1.38,31.89]}\end{array}$ & 0.018 \\
\hline $\begin{array}{l}\text { High MUAC } \\
(\geq 23 \mathrm{~cm})\end{array}$ & $194(65.6)$ & $88(29.7)$ & $14(4.7)$ & Reference & Reference & & Reference & Reference & \\
\hline $\begin{array}{l}\text { Perinatal } \\
\text { depression }\end{array}$ & \multicolumn{9}{|c|}{$P$-value $=0.015$} \\
\hline Yes & $26(72.2)$ & $5(13.9)$ & $5(13.9)$ & $\begin{array}{l}2.30 \\
{[0.86,6.15]}\end{array}$ & $\begin{array}{l}2.56 \\
{[0.88,7.46]}\end{array}$ & 0.086 & $\begin{array}{l}7.54 \\
{[1.92,29.61]}\end{array}$ & $\begin{array}{l}12.50 \\
{[2.72,57.54]}\end{array}$ & 0.001 \\
\hline No & $222(66.7)$ & $98(29.4)$ & $13(3.9)$ & Reference & Reference & & Reference & Reference & \\
\hline
\end{tabular}


Table 4 (continued)

\begin{tabular}{|c|c|c|c|c|c|c|c|c|c|}
\hline \multirow[b]{2}{*}{ Variable } & \multicolumn{3}{|c|}{ Proportions of GWG } & \multicolumn{3}{|c|}{ Inadequate vs Adequate } & \multicolumn{3}{|c|}{ Excess vs Adequate } \\
\hline & $\begin{array}{l}\text { Inadequate } \\
\text { GWG n(\%) }\end{array}$ & $\begin{array}{l}\text { Adequate } \\
\text { GWG n(\%) }\end{array}$ & $\begin{array}{l}\text { Excess GWG } \\
\mathrm{n}(\%)\end{array}$ & $\begin{array}{l}\text { Crude Odds } \\
\text { Ratio (COR) }\end{array}$ & $\begin{array}{l}\text { Adjusted } \\
\text { Odds Ratio } \\
\text { (AOR) }\end{array}$ & $\begin{array}{l}P \text {-value for } \\
\text { AOR }\end{array}$ & $\begin{array}{l}\text { Crude Odds } \\
\text { Ratio (COR) }\end{array}$ & $\begin{array}{l}\text { Adjusted } \\
\text { Odds Ratio } \\
\text { (AOR) }\end{array}$ & $\begin{array}{l}P \text {-value for } \\
\text { AOR }\end{array}$ \\
\hline $\begin{array}{l}\text { Asking } \\
\text { permis- } \\
\text { sion from } \\
\text { partners for } \\
\text { health care } \\
\text { seeking }\end{array}$ & \multicolumn{9}{|c|}{$P$-value $=0.123$} \\
\hline Yes & $112(73.2)$ & $34(22.2)$ & $7(4.6)$ & $\begin{array}{l}1.65 \\
{[1.02,2.67]}\end{array}$ & $\begin{array}{l}1.44 \\
{[0.83,2.50]}\end{array}$ & 0.191 & $\begin{array}{l}1.27 \\
{[0.45,3.58]}\end{array}$ & $\begin{array}{l}1.98 \\
{[0.59,6.70]}\end{array}$ & 0.270 \\
\hline No & $136(63.3)$ & $68(31.6)$ & $11(5.1)$ & Reference & Reference & & Reference & Reference & \\
\hline Age & \multicolumn{9}{|c|}{$P$-value $=0.965$} \\
\hline $\begin{array}{l}\text { Less than } \\
20 \text { years }\end{array}$ & $12(66.7)$ & $6(33.3)$ & 0 & $\begin{array}{l}0.83 \\
{[0.30,2.28]}\end{array}$ & NA & NA & - & NA & NA \\
\hline 20-29 years & $198(66.7)$ & $82(27.6)$ & $17(5.7)$ & Reference & NA & NA & Reference & NA & NA \\
\hline $30-40$ years & $38(70.4)$ & $15(27.8)$ & $1(1.8)$ & $\begin{array}{l}1.05 \\
{[0.55,2.01]}\end{array}$ & NA & NA & $\begin{array}{l}0.32 \\
{[0.04,2.60]}\end{array}$ & NA & NA \\
\hline $\begin{array}{l}\text { Partners' } \\
\text { educational } \\
\text { status (369) }\end{array}$ & \multicolumn{9}{|c|}{$P$-value $=0.782$} \\
\hline $\begin{array}{l}\text { No formal } \\
\text { education }\end{array}$ & $25(83.3)$ & $5(16.7)$ & 0 & $\begin{array}{l}2.43 \\
{[0.86,6.90]}\end{array}$ & NA & NA & - & NA & NA \\
\hline $\begin{array}{l}\text { Primary } \\
\text { education } \\
(1-8)\end{array}$ & $62(65.3)$ & $27(28.4)$ & $6(6.3)$ & $\begin{array}{l}1.12 \\
{[0.61,2.05]}\end{array}$ & NA & NA & $\begin{array}{l}1.26 \\
{[0.36,4.35]}\end{array}$ & NA & NA \\
\hline $\begin{array}{l}\text { Secondary } \\
\text { education } \\
(9-12)\end{array}$ & $91(67.9)$ & $37(27.6)$ & $6(4.5)$ & $\begin{array}{l}1.19 \\
{[0.68,2.09]}\end{array}$ & NA & NA & $\begin{array}{l}0.92 \\
{[0.27,3.12]}\end{array}$ & NA & NA \\
\hline $\begin{array}{l}\text { Tertiary edu- } \\
\text { cation }\end{array}$ & $70(63.6)$ & $34(30.9)$ & $6(5.5)$ & Reference & & NA & Reference & Reference & \\
\hline $\begin{array}{l}\text { Minimum } \\
\text { dietary } \\
\text { diversity }\end{array}$ & \multicolumn{9}{|c|}{$P$-value $=0.851$} \\
\hline $\begin{array}{l}\text { Low dietary } \\
\text { diversity }\end{array}$ & $47(70.1)$ & $17(25.4)$ & $3(4.5)$ & $\begin{array}{l}1.18 \\
{[0.64,2.18]}\end{array}$ & NA & NA & $\begin{array}{l}1.01 \\
{[0.26,3.88]}\end{array}$ & NA & NA \\
\hline $\begin{array}{l}\text { High dietary } \\
\text { diversity }\end{array}$ & $201(66.5)$ & $86(28.5)$ & $15(5.0)$ & Reference & NA & NA & Reference & NA & NA \\
\hline $\begin{array}{l}\text { Food insecu- } \\
\text { rity }\end{array}$ & \multicolumn{9}{|c|}{$P$-value $=0.903$} \\
\hline Food secure & $212(67.1)$ & $89(28.2)$ & $15(4.7)$ & Reference & NA & NA & Reference & NA & NA \\
\hline $\begin{array}{l}\text { Food inse- } \\
\text { cure }\end{array}$ & $33(67.4)$ & 13 (26.5) & $3(6.1)$ & $\begin{array}{l}1.07 \\
{[0.54,2.12]}\end{array}$ & NA & NA & $\begin{array}{l}1.37 \\
{[0.35,5.39]}\end{array}$ & NA & NA \\
\hline $\begin{array}{l}\text { Intimate } \\
\text { partner } \\
\text { violence }\end{array}$ & \multicolumn{9}{|c|}{$P$-value $=0.335$} \\
\hline Yes & $44(62.8)$ & $24(34.3)$ & $2(2.9)$ & $\begin{array}{l}0.71 \\
{[0.41,1.24]}\end{array}$ & NA & NA & $\begin{array}{l}0.41 \\
{[0.09,1.92]}\end{array}$ & NA & NA \\
\hline No & $204(68.2)$ & 79 (26.4) & $16(5.4)$ & Reference & NA & NA & Reference & NA & NA \\
\hline $\begin{array}{l}\text { Type of } \\
\text { pregnancy } \\
\text { (363) }\end{array}$ & \multicolumn{9}{|c|}{$P$-value $=0.990$} \\
\hline Intended & $221(67.0)$ & 91 (27.6) & 18(5.4.) & Reference & NA & NA & Reference & NA & NA \\
\hline Unintended & $23(69.7)$ & $10(30.3)$ & 0 & $\begin{array}{l}0.95 \\
{[0.43,2.07]}\end{array}$ & NA & NA & - & NA & NA \\
\hline
\end{tabular}


Table 4 (continued)

\begin{tabular}{|c|c|c|c|c|c|c|c|c|c|}
\hline \multirow[b]{2}{*}{ Variable } & \multicolumn{3}{|c|}{ Proportions of GWG } & \multicolumn{3}{|c|}{ Inadequate vs Adequate } & \multicolumn{3}{|c|}{ Excess vs Adequate } \\
\hline & $\begin{array}{l}\text { Inadequate } \\
\text { GWG n(\%) }\end{array}$ & $\begin{array}{l}\text { Adequate } \\
\text { GWG n(\%) }\end{array}$ & $\begin{array}{l}\text { Excess GWG } \\
n(\%)\end{array}$ & $\begin{array}{l}\text { Crude Odds } \\
\text { Ratio (COR) }\end{array}$ & $\begin{array}{l}\text { Adjusted } \\
\text { Odds Ratio } \\
\text { (AOR) }\end{array}$ & $\begin{array}{l}P \text {-value for } \\
\text { AOR }\end{array}$ & $\begin{array}{l}\text { Crude Odds } \\
\text { Ratio (COR) }\end{array}$ & $\begin{array}{l}\text { Adjusted } \\
\text { Odds Ratio } \\
\text { (AOR) }\end{array}$ & $\begin{array}{l}P \text {-value for } \\
\text { AOR }\end{array}$ \\
\hline $\begin{array}{l}\text { Number of } \\
\text { pregnancy } \\
(369)\end{array}$ & \multicolumn{9}{|c|}{$P$-value $=0.333$} \\
\hline $\begin{array}{l}\text { First preg- } \\
\text { nancy }\end{array}$ & $116(64.8)$ & $55(30.7)$ & $8(4.5)$ & Reference & NA & NA & Reference & NA & NA \\
\hline Second & $80(74.1)$ & $25(23.1)$ & $3(2.8)$ & $\begin{array}{l}1.52 \\
{[0.87,2.63]}\end{array}$ & NA & NA & $\begin{array}{l}0.83 \\
{[0.20,3.37]}\end{array}$ & NA & NA \\
\hline Third & $36(67.9)$ & $13(24.5)$ & $4(7.6)$ & $\begin{array}{l}1.31 \\
{[0.63,2.67]}\end{array}$ & NA & NA & $\begin{array}{l}2.12 \\
{[0.55,8.12]}\end{array}$ & NA & NA \\
\hline $\begin{array}{l}\text { Fourth and } \\
\text { above }\end{array}$ & $16(55.2)$ & $10(34.5)$ & $3(10.3)$ & $\begin{array}{l}0.76 \\
{[0.32,1.78]}\end{array}$ & NA & NA & $\begin{array}{l}2.06 \\
{[0.47,9.13]}\end{array}$ & NA & NA \\
\hline $\begin{array}{l}\text { Level of } \\
\text { physical } \\
\text { activity } \\
\text { (369) }\end{array}$ & \multicolumn{9}{|c|}{$P$-value $=0.633$} \\
\hline Low & $120(68.6)$ & $47(26.8)$ & $8(4.6)$ & $\begin{array}{l}1.60 \\
{[0.77,3.30]}\end{array}$ & NA & NA & $\begin{array}{l}2.55 \\
{[0.29,22.10]}\end{array}$ & NA & NA \\
\hline Moderate & $104(67.5)$ & $41(26.6)$ & $9(5.9)$ & $\begin{array}{l}1.59 \\
{[0.76,3.32]}\end{array}$ & NA & NA & $\begin{array}{l}3.29 \\
{[0.38,28.24]}\end{array}$ & NA & NA \\
\hline High & $24(60.0)$ & $15(37.5)$ & $1(2.5)$ & Reference & NA & NA & Reference & NA & NA \\
\hline
\end{tabular}

$N A^{*}$ not illegible to be included into multivariable regression because the $p$-values were $>0.25$ in bi-variable regression

our study participants not having paid employment at the time of data collection. This high proportion of women's unemployment is associated with women's educational status. About half of our study participants attended no formal education or only attended primary education. Maternal education would help women to generate income through employment, as educated women are more likely to have paid work than uneducated women [70]. A study from China also reported that unemployment, housework or temporary work increased the odds of inadequate GWG compared to regular paid employment outside the home [71]. Improving women's employment status would be important to prevent inappropriate GWG.

While studies from high-income countries reported that household food insecurity is associated with excessive GWG [32, 33], household food insecurity was not significantly associated with GWG in our study. Women's dietary diversity, intimate partner violence and physical activity were not significantly associated with GWG.

Previous studies have reported that perinatal depression is associated with gaining inadequate gestational weight [25] or excessive GWG [72, 73], while another study reported perinatal depression was not associated with either inadequate or excessive GWG [74]. In our study, perinatal depression was not associated with inadequate GWG, but associated with excessive GWG.
However, since few women in our study gained excessive gestational weight and those findings had a wide confidence interval, this is not strong evidence to conclude that perinatal depression is associated with excessive GWG.

About half of our study participants (47.1\%) reported that they engaged in low-level physical activity. Physical activity was not significantly associated with GWG in our study. The women in our study used the highest amount of energy on household activities. This could be due to $50 \%$ of our study participants being unemployed (identified themselves as undertaking home duties), which could have accounted for the low energy expenditure on occupational activity. Another possible reason could be most pregnant women may feel safer and comfortable doing household activities than engaging in occupational or sports activities during pregnancy [75].

This study has some limitations. Firstly, the IOM GWG recommendations are the recommendations of highincome countries. These recommendations may not be suitable in low-income settings such as Ethiopia. Secondly, we measured pre-pregnancy BMI before or at 16 weeks of gestation, at which time there may already have been an increase or decrease of gestational weight. In addition, women's last weight was measured at 36 weeks of gestation; hence there may be some weight gain after 36 weeks of gestation. Finally, this study was conducted in the capital city 
of Ethiopia in the public health facilities; the situation in other parts of the country and private health facilities may be different. Future research may need to investigate the effect of GWG on pregnancy outcomes.

\section{Conclusion}

Nearly two-thirds of our study participants gained inadequate gestational weight. Pre-pregnancy BMI and occupational status of the women were strong predictors of GWG. Preconception or early pregnancy GWG-related counselling and intervention(s) regarding the best GWG management approach would be a public health priority. The practical applicability of the IOM guidelines and the effect of GWG (according to IOM recommendations) on pregnancy outcomes need further investigation in Ethiopian context.

\section{Abbreviations}

ANC: Antenatal Care; AOR: Adjusted Odds Ratio; BMl: Body Mass Index; EPDS: Edinburgh Postnatal Depression Scale; FAO: Food and Agricultural Organisation; GWG: Gestational Weight Gain; HFIAS: Household Food Insecurity Access Scale; IOM: Institute of Medicine; IQR: Inter Quartile Range; IPAQ: International Physical Activity Questionnaire; LBW: Low Birth Weight; MDD-W: Women's-Minimum Dietary Diversity; MET: Metabolic Equivalent Task; MUAC: Mid-Upper Arm Circumferences; USAID: United States Agency for International Development.

\section{Supplementary Information}

The online version contains supplementary material available at https://doi. org/10.1186/s12978-021-01202-y.

Additional file 1. Table S1: Number of women participated from different health centres, Addis Ababa, Ethiopia, 2019

\section{Acknowledgements}

We would like to thank an Australian Government Research Training Program for providing a scholarship to Fekede Asefa.

\section{Authors' contributions}

FA has conceived the study, performed data collection and analyses, and drafted the manuscript. AH, MF, YD and AC have also conceived the study and critically revised the design of the study, participated in the analyses, interpretation of the findings and draft of the manuscript. All authors read and approved the final manuscript.

\section{Funding}

This research was partially funded by Haramaya University, Ethiopia as part of staff grant [grant number:HURG_2018_02_01_30]. The funder has no role in the design of the study and collection, analysis, and interpretation of data and in writing the manuscript.

\section{Availability of data and materials}

The datasets used for the analysis are available from the corresponding author on reasonable request.

\section{Declarations}

\section{Ethics approval and consent to participate}

Ethics approval for the study was obtained from the Haramaya University Institutional Health Research Ethics Review Committee [IHRERC/200/2018], Addis Ababa Health Bureau Institutional Review Board [A/A/HB/2576/227] and the University of Technology Sydney, Human Research Ethics Committee [UTS HREC18-2610].

\section{Consent for publication}

Informed consent was obtained from all participants for publication.

\section{Competing interests}

The authors declare that they have no competing interests.

\section{Author details}

${ }^{1}$ School of Public Health, College of Health and Medical Sciences, Haramaya University, Harar, Ethiopia. ${ }^{2}$ Centre for Midwifery, Child and Family Health, Faculty of Health, University of Technology Sydney, Ultimo, Sydney, NSW, Australia. ${ }^{3}$ School of Public Health, Faculty of Health, University of Technology Sydney, Ultimo, Sydney, NSW, Australia. ${ }^{4}$ Hunter New England Health, Nursing and Midwifery Research Centre, University of Newcastle, Newcastle, NSW, Australia.

Received: 9 October 2020 Accepted: 12 July 2021

Published online: 28 July 2021

\section{References}

1. Institute of Medicine. Weight gain during pregnancy: reexamining the guidelines. Washington: National Academy Press; 2009. https://www. cbsnews.com/htdocs/pdf/052809_pregnancy.pdf. Accessed 30 Sept 2017.

2. Johnson J, Clifton RG, Roberts JM, Myatt L, Hauth JC, Spong CY, Varner MW, Wapner RJ, Thorp JM, Mercer BM, et al. Pregnancy outcomes with weight gain above or below the 2009 institute of medicine guidelines. Obstet Gynecol. 2013;121(5):969-75.

3. Torre LDL, Flick AA, Istwan N, Rhea D, Cordova Y, Dieguez C, Desch C, Lez-Quintero VHG. The effect of new antepartum weight gain guidelines and prepregnancy body mass index on the development of pregnancyrelated hypertension. Am J Perinatol. 2011;28(4):285-91.

4. Ashley-Martin J, Woolcott C. Gestational weight gain and postpartum weight retention in a cohort of Nova Scotian Women. Matern Child Health J. 2014;18(8):1927-35.

5. Asefa F, Nemomsa D. Gestational weight gain and its associated factors in Harari Regional State: Institution based cross-sectional study, Eastern Ethiopia. BMC Reprod Health. 2016;13(1):1-7.

6. Begum F, Colman I, McCargar LJ, Bell RC. Gestational weight gain and early postpartum weight retention in a prospective cohort of alberta women. J Obstet Gynaecol Can. 2012;34(7):637-47.

7. Restall A, Taylor RS, Thompson JD, Flower D, Dekker GA, Kenny LC, Poston L, McCowan LE. Risk factors for excessive gestational weight gain in a healthy, Nulliparous Cohort. J Obes. 2014. https://doi.org/10.1155/2014/ 148391.

8. Wrottesley SV, Pisa PT, Norris SA. The influence of maternal dietary patterns on body mass index and gestational weight gain in urban black South African Women. Nutrients. 2017;9(732):1-14.

9. Muyayalo KP, Olivia NA, Mbungu MR. Postpartum weight retention in congolese pregnant in Kinshasa. Int J Cur Res Rev. 2017;9(18):29-35.

10. Halle-Ekane GE, Nsom JB, Atashili J, Palle JN, Nsagha DS, Nguefack CT, Njotang PN. Outcome of pregnancy in patients with excessive gestational weight gain in two district hospitals in Douala, Cameroon. SM Gynecol Obstet. 2015;1(1):1-6.

11. Adu-Afarwuah S, Lartey A, Okronipa H, Ashorn P, Ashorn U, Zeilani M, Arimond M, Vosti SA, Dewey KG. Maternal supplementation with smallquantity lipid-based nutrient supplements compared with multiple micronutrients, but not with iron and folic acid, reduces the prevalence of low gestational weight gain in semi-urban Ghana: a randomized controlled trial. J Nutr Diet. 2017;147(4):697-705.

12. Asefa F, Cummins A, Dessie Y, Hayen A, Foureur M. Gestational weight gain and its effect on birth outcomes in sub-Saharan Africa: systematic review and meta-analysis. PLoS ONE. 2020;15(4):1-23.

13. Wang D, Wang M, Darling AM, Perumal N, Liu E, Danaei G, Fawzi WW. Gestational weight gain in low-income and middle-income countries: a modelling analysis using nationally representative data. BMJ Glob Health. 2020; 5(11):1-9. 
14. Wanyama R, Obai G, Odongo P, Kagawa MN, Baingana RK. Are women in Uganda gaining adequate gestational weight? A prospective study in low income urban Kampala. Reprod Health. 2018;15(1):1-8.

15. Hickey CA. Sociocultural and behavioral influences on weight gain during pregnancy. Am J Clin Nutr. 2000;71(suppl):1364S-1370S.

16. Ehrenberg HM, Dierker L, Milluzzi C, Mercer BM. Low maternal weight, failure to thrive in pregnancy, and adverse pregnancy outcomes. Am J Obstet Gynecol. 2003;189(6):1726-30.

17. Haugen M, Brantsæter AL, Winkvist A, Lissner L, Alexander J. Bente Oftedal1, Magnus P, Meltzer HM: Associations of pre-pregnancy body mass index and gestational weight gain with pregnancy outcome and postpartum weight retention: a prospective observational cohort study. BMC Pregnancy Childbirth. 2015;14(201):1-11.

18. Endalamaw A, Engeda EH, Ekubagewargies DT, Belay GM, Tefera MA. Low birth weight and its associated factors in Ethiopia: a systematic review and meta-analysis. Ital J Pediatr. 2018;44(1):1-12.

19. Bekele I, Demeke T, Dugna K. Prevalence of preterm birth and its associated factors among mothers delivered in Jimma University Specialized Teaching and Referral Hospital, Jimma Zone, Oromia Regional State, South West Ethiopia. J Women's Health Care. 2017;6(1):1-10.

20. Chung JGY, Taylor RS, Thompson JMD, Ngaire H. Anderson a, Dekker GA, Kenny LC, McCowan LME: Gestational weight gain and adverse pregnancy outcomes in a nulliparous cohort. Eur J Obstet Gynecol. 2013;167(2):149-53.

21. Mamun AA, Kinarivala M, O'Callaghan MJ, Williams GM, Najman JM, Callaway LK. Associations of excess weight gain during pregnancy with longterm maternal overweight and obesity: evidence from 21 y postpartum follow-up. Am J Clin Nutr. 2010;91:1336-41.

22. Criss S, Oken E, Guthrie L, Hivert M-F. A qualitative study of gestational weight gain goal setting. BMC Pregnancy Childbirth. 2016;16(317):1-8.

23. Cole KOW, Gudzune KA, Bleich SN, Bennett WL, Cheskin LJ, Henderson JL, Caulfield LE, Guan Y, Roter DL. Influence of the 5A's counseling strategy on weight gain during pregnancy: an observational study. J Women's Health. 2017;26(10):1123-30.

24. Yeo S, Crandell JL, Jones-Vessey K. Adequacy of prenatal care and gestational weight gain. J Women's Health. 2016;25(2):117-23.

25. Bodnar LM, Wisner KL, Moses-Kolko E, Sit DKY, Hanusa BH. Prepregnancy body mass index, gestational weight gain and the likelihood of major depression during pregnancy. J Clin Psychiatry. 2009;70(9):1290-6.

26. Kubo A, Ferrara A, Brown SD, Ehrlich SF, Tsai A-L, Quesenberry CP, Crites $Y$, Hedderson MM. Perceived psychosocial stress and gestational weight gain among women with gestational diabetes. PLoS ONE. 2017;12(3):1-11.

27. McDonald SD, Park CK, Timm V, Schmidt L, Neupane B, Beyene J. What psychological, physical, lifestyle, and knowledge factors are associated with excess or inadequate weight gain during pregnancy? A crosssectional survey. J Obstet Gynaecol Can. 2013;35(11):1071-82.

28. Beyerlein A, Nehring I, Rzehak P, Heinrich J, Ller MJM, Plachta-Danielzik S, Wabitsch M, Weck M, Brenner H, Rothenbacher D, et al. Gestational weight gain and body mass index in children: results from three german cohort studies. PLoS ONE. 2012;7(3):1-7.

29. Schlaff RA, Holzman C, Mudd LM, Pfeiffer K, Pivarnik J. Body mass index is associated with appropriateness of weight gain but not leisure-time physical activity during pregnancy. J Phys Act Health. 2014;1 1(8):1593-9.

30. Hill B, Skouteris H, Fuller-Tyszkiewicz M, Kothe EJ, McPhie S. A path model of psychosocial and health behaviour change predictors of excessive gestational weight gain. J Reprod Infant Psychol. 2016;34(2):139-61.

31. McDonalda SM, Liub J, Wilcoxa S, Laua EY, Archerc E. Does dose matter in reducing gestational weight gain in exercise interventions? A systematic review of literature. J Sci Med Sport. 2016;19(4):323-35.

32. Laraia BA, Siega-Riz AM, Gundersen C. Household food insecurity is associated with self-reported pregravid weight status, gestational weight gain, and pregnancy complications. J Am Diet Assoc. 2010;110(5):692-701.

33. Olson CM, Strawderman MS. The relationship between food insecurity and obesity in rural childbearing women. J Rural Health. 2008;24(1):60-6.

34. Saaka M. How is household food insecurity and maternal nutritional status associated in a resource-poor setting in Ghana? BMC Agric Food Secur. 2016;5(11):1-8.

35. Na M, Mehra S, Christian P, Ali H, Shaikh S, Shamim AA, Labrique AB, Klemm RD, Wu LS Jr, KPW. Maternal dietary diversity decreases with household food insecurity in rural bangladesh: a longitudinal analysis. J Nutr. 2016;146(10):2109-16.

36. Isanaka S, Mora-Plazas M, Lopez-Arana S, Baylin A, Villamor E. Food insecurity is highly prevalent and predicts underweight but not overweight in adults and school children from Bogota', Colombia. J Nutr. 2007;137(12):2747-55.

37. Motbainor A, Worku A, Kumie A. Household food insecurity is associated with both body mass index and middle upper-arm circumference of mothers in northwest Ethiopia: a comparative study. Int J Women's Health. 2017;9:379-89.

38. Ghose B, Tang S, Yaya S, Feng Z. Association between food insecurity and anemia among women of reproductive age. Peer J. 2016; 4(e1945):1-12

39. Jones AD. Food Insecurity and Mental Health Status: A Global Analysis of 149 Countries. Am J Prev Med. 2017;53(2):264-73.

40. Moraes CL, Amorim AR, Reichenheim ME. Gestational weight gain differentials in the presence of intimate partner violence. Int J Gynecol Obstet. 2006;95(3):254-60.

41. Kearney MH, Munro BH, Kelly U, Hawkins JW. Health behaviors as mediators for the effect of partner abuse on infant birth weight. Nurs Res. 2004;53(1):36-45.

42. Central Statistical Agency: ETHIOPIA Demographic and Health Survey 2016 Key Indicators Report. Central Statistical Agency, Addis Ababa, Etthiopia and The DHS Program ICF Rockville, Maryland, USA; 2016. https://dhsprogram.com/pubs/pdf/FR328/FR328.pdf. Accessed 23 Nov 2020.

43. Nemomsa D, Mesfin F, Damena M, Asefa F. Early-pregnancy Body Mass Index and GestationalWeightGain are important Maternal Markers of LowBirth Weight in Harar town Eastern Ethiopia. EAJHBS. 2018;2(1):1-9.

44. Tela FG, Bezabih AM, Adhanu AK. Effect of pregnancy weight gain on infant birth weight among mothers attending antenatal care from private clinics in Mekelle City, Northern Ethiopia: a facility based follow-up study. PLoS ONE. 2019;14(3):1-10.

45. Ministry of Health. Health sector transformation plan-l: annual performance report. Ethiopia: Federal Democratic Republic of Ethiopia, Ministry of Health; 2017. http://repository.iifphc.org/handle/123456789/320. Accessed 10 July 2021.

46. Federal Ministry of Health. Health and health related indicators 2009EFY (2016/2017). Addis Ababa: Federal Ministry of Health; 2017. https://www. moh.gov.et/ejcc/sites/default/files/2020-01/Ethiopia\%207th\%20Health\% 20Accounts\%20Report_2016-17.pdf. Accessed 10 July 2021.

47. Tegegne TK, Chojenta C, Getachew T, Smith R, Loxton D. Antenatal care use in Ethiopia: a spatial and multilevel analysis. BMC Pregnancy Childbirth. 2019;19(1):1-16.

48. Rutstein SO. Steps to constructing the new DHSWealth Index. In. Rockville: ICF International; 2015. https://dhsprogram.com/programming/ wealth\%20index/Steps_to_constructing_the_new_DHS_Wealth_Index. pdf. Accessed 5 Oct 2019.

49. FAO, FHI 360. Minimum dietary diversity for women: a guide for measurement. Rome: FAO; 2016. http://www.fao.org/3/a-i5486e.pdf. Accessed 10 Nov 2017.

50. Coates J, Swindale A, Bilinsky P. Household Food Insecurity Access Scale (HFIAS) for Measurement of Household Food Access: Indicator Guide In. Washington: Food and Nutrition Technical Assistance Project, USAID; 2007. https://www.fantaproject.org/sites/default/files/resources/HFIAS_ ENG_v3_Aug07.pdf. Accessed 10 Jan 2018.

51. IPAQ: Guidelines for Data Processing and Analysis of the International Physical Activity Questionaire (IPAQ). The International Physical Activity Questionnaire, 2014. www.ipaq.ki.se.

52. Ainsworth BE, Haskell WL, Herrmann SD, Meckes N, Tudor-Locke C, Greer JL, Vezina J, Whitt-Glover MC, Leon AS. 2011 compendium of physical activities: a second update of codes and MET values. Med Sci Sports Exerc. 2011;43(8):1575-81

53. Murray D, Cox JL. Screening for depression during pregnancy with the edinburgh depression scale (EDDS). J Reprod Infant Psychol. 1990;8(2):99-107.

54. Biratu A, Haile D. Prevalence of antenatal depression and associated factors among pregnant women in Addis Ababa, Ethiopia: a cross-sectional study. Reprod Health. 2015;12(99):1-8.

55. Bisetegn TA, Mihretie G, Muche T. Prevalence and predictors of depression among pregnantwomen in debretabor town Northwest Ethiopia. PLOS ONE. 2016;11(9):1-10. 
56. Hanlona C, Medhin G, Alem A, Mesfin A, Abdulahi A, Hughesa M, Markos Tesfaye B, Wondimagegn D, Patel V, Prince M. Detecting perinatal common mental disorders in Ethiopia: validation of the self-reporting questionnaire and edinburgh postnatal depression scale. J Affect Disord. 2008;108(3):251-62.

57. Tesfaye M, Hanlon C, Wondimagegn D, Alem A. Detecting postnatal common mental disorders in Addis Ababa, Ethiopia: validation of the edinburgh postnatal depression scale and kessler scales. J Affect Disord. 2010:2010(122):102-8.

58. García-Moreno C, Jansen HAFM, Ellsberg M, Heise L, Watts C. WHO multi-country study on women's health and domestic violence against women : initial results on prevalence, health outcomes and women's responses. Geneva: World Health Organisation; 2005. Accessed on January 20, 2018, from: https://www.who.int/reproductivehealth/ publications/violence/24159358X/en/

59. Gedamu H, Tsegaw A, Debebe E. The prevalence of traditional malpractice during pregnancy, child birth, and postnatal period among women of childbearing age in Meshenti Town. Int J Reprod Med . 2016;2018:1-7.

60. Zerfu TA, Umeta M, Baye K. Dietary habits, food taboos, and perceptions towards weight gain during pregnancy in Arsi, rural central Ethiopia: a qualitative cross-sectional study. J Health Popul Nutr. 2016;35(22):1-7.

61. Gondwe A, Ashorn P, Ashorn U, Dewey KG, Maleta K, Nkhoma M, Mbotwa J, Jorgensen JM. Pre-pregnancy body mass index (BMI) and maternal gestational weight gain are positively associated with birth outcomes in rural Malawi. PLOS ONE. 2018;13(10):1-15.

62. Ouédraogo CT, Wessells KR, Young RR, Faye MT, Hess SY. Prevalence and determinants of gestational weight gain among pregnant women in Niger. Matern Child Nutr. 2020; 16(1):1-15.

63. Lindsay KL, Gibney ER, McAuliffe FM. Maternal nutrition among women from Sub-Saharan Africa, with a focus on Nigeria, and potential implications for pregnancy outcomes among immigrant populations in developed countries. J Hum Nutr Diet. 2012;25(6):534-46.

64. Esimai OA, Ojofeitimi E. Pattern and determinants of gestational weight gain an important predictor of infant birth weight in a developing country. Global J Health Sci. 2014;6(4):148-54.

65. Olagbuji BN, Olofinbiyi BA, Akintayo AA, Aduloju OP, Ade-Ojo PI. Maternal perspectives on gestational weight gain: critical information on developing weight control interventions. Niger Med J. 2015;56(2):96-102.
66. Wen T, LVY. Inadequate gestational weight gain and adverse pregnancy outcomes among normal weight women in China. Int J Clin Exp Med. 2015;8(2):2881-6.

67. Davis-Moss RR, Hofferth SL. Inadequate gestational weight gain and malnutritionrelated causes of infant death. J Pregnancy Reprod. 2018;2(3):1-5.

68. Ikenoue S, Miyakoshi K, Kasuga Y, Ochiai D, Matsumoto T, Tanaka M. Impaired fetal growth in mothers with inadequate gestational weight gain: a retrospective study in Japanese uncomplicated pregnancy. J Matern Fetal Neonatal Med. 2018;33(13):2227-31.

69. Mohannad A, Rizvi F, Irfan G. Impact of maternal education, and socioeconomic status on maternal nutritional knowledge and practices regarding iron rich foods and iron supplements. Ann Pak Inst Med Sci. 2012;8(2):101-5.

70. Mahdi S, Agheli L, Arani AA, Sadeghi H. The effect of mothers' education and employment on children's health. Jentashapir J Health Res. 2016;7(4):1-4.

71. Min J, Li Z, Liu X, Wang Y. The association between early menarche and offspring's obesity risk in early childhood was modified by gestational weight gain. Obesity; 22(1):19-23.

72. Casanueva E, Labastida J, Sanz C, Morales-Carmona F. Depression and body fat deposition in mexican pregnant adolescents. Arch Med Res. 2000;31(1):48-52.

73. Web GJB, Siega-Riz AM, Dole N. Psychosocial Determinants of Adequacy of Gestational Weight. Obesity. 2009;17(2):300-9.

74. Molyneaux E, Poston L, Khondoker M, Howard LM. Obesity, antenatal depression, diet and gestational weight gain in a population cohort study. Arch Womens Ment Health. 2016;19(5):899-907.

75. Gebregziabher D, Berhe H, Kassa M, Berhanie E. Level of physical activity and associated factors during pregnancy among women who gave birth in Public Zonal Hospitals of Tigray. BMC Res Notes. 2019. https://doi.org/ 10.1186/s13104-019-4496-5.

\section{Publisher's Note}

Springer Nature remains neutral with regard to jurisdictional claims in published maps and institutional affiliations.
Ready to submit your research? Choose BMC and benefit from:

- fast, convenient online submission

- thorough peer review by experienced researchers in your field

- rapid publication on acceptance

- support for research data, including large and complex data types

- gold Open Access which fosters wider collaboration and increased citations

- maximum visibility for your research: over 100M website views per year

At BMC, research is always in progress.

Learn more biomedcentral.com/submissions 